\title{
CURRENT DISTRIBUTION OF GOLDEN POTATO CYST NEMATODE, GLOBODERA ROSTOCHIENSIS (TYLENCHIDA, HETERODERIDAE), IN UKRAINE
}

\author{
O. I. Borzykh ${ }^{1}$, D. D. Sigareva1, O. L. Fedorenko', T. I. Bondar ${ }^{1}$, V. V. Kornyushin ${ }^{2}$, \\ O. O. Sokolova ${ }^{2}$, V. G. Karpliuk ${ }^{3}$
}

${ }^{1}$ Institute of Plant Protection, NAAS of Ukraine,

Vasylkivska st., 33, Kyiv, 03022 Ukraine

${ }^{2 * S h m a l h a u s e n ~ I n s t i t u t e ~ o f ~ Z o o l o g y ~ N A S ~ o f ~ U k r a i n e, ~}$

vul. B. Khmelnitskogo, 15, Kyiv, 01030 Ukraine

${ }^{3}$ Kyiv region Department of the State Service of Ukraine for food safety and consumer protection,

Saperno-Slobidska st., 8, Kyiv, 03028 Ukraine

${ }^{*}$ Corresponding author

E-mail:vadikorn@izan.kiev.ua

Current Distribution of Golden Potato Cyst Nematode, Globodera rostochiensis (Tylenchida, Heteroderidae), in Ukraine. Borzykh, O. I. Sygareva, D. D., Fedorenko, O. L., Bondar, T. I., Kornyushin, V. V., Sokolova, O. O., Karpliuk, V. G. - Globodera infestation was evaluated in soils of private farm plots in Chernihiv and Kyiv regions of Ukraine in 2017-2018. Soil samples were taken at 88 farms, 15.02 ha in total, in 11 settlements of 6 districts. The nematode abundance in the examined areas was graded as follows: less than 1000 eggs + larvae $/ 100 \mathrm{~cm}^{3}-$ low rate of infestation; $1000-5000$ eggs + larvae $/ 100 \mathrm{~cm}^{3}$ - average rate; more than 5000 eggs + larvae $/ 100 \mathrm{~cm}^{3}$ - high rate. $85.4 \%$ of study area is infested with the golden potato cyst nematode. The mean abundance of pest was $3331(15-23,237)$ eggs+larvae/100 $\mathrm{cm}^{3}$ : including $8730(91-21,486)$ eggs+larvae/100 $\mathrm{cm}^{3}$ in Kyiv Region and $1829.6(15-$ 23,237) eggs+larvae/100 $\mathrm{cm}^{3}$ in Chernihiv Region. The highest number of assessed plots per district (29) was in Koryukivsky District, and the mean abundance of G. rostochiensis (Ro-1) was $1549(20-15,757)$ eggs + larvae $/ 100 \mathrm{~cm}^{3} \mathrm{e}+1 / 100 \mathrm{~cm}^{3}$. We also analyzed the results of golden nematode monitoring conducted by the State Service of Ukraine for food safety and consumer protection in 2018. According to those, the golden nematode is found in 18 regions of Ukraine. In most of those (14 regions), the pest infests rather small areas, less than 500 ha. Globodera is not recorded in the other 7 regions of Ukraine and Autonomous Republic of Crimea for now.

Key words: golden potato cyst nematode, Globodera rostochiensis, soil infestation rate, cyst, distribution, Ukraine 


\section{Introduction}

Globodera rostochiensis (Wollenweber, 1923), Skarbilovich, 1959 is the golden potato cyst nematode, one of the sedentary endoparasitic cyst nematodes of the genus Globodera, Heteroderidae, superfamily Tylenchoidea (Filipjev, 1934) B. Chitwood \& M. Chitwood, 1937. This species is one of the most harmful pathogens of potatoes (Nikitin, 1972). The nematode causes potato globoderosis and is included in the "List of regulated pests" as a quarantined organism with a limited distribution on the territory of Ukraine (Review of distribution of quarantined organisms in 2018). Well-defined sexual dimorphism is characteristic of this species. The males have long, nematode-like, translucent body, and the females have a swollen spherical or lemon-shaped body with a small finger-shaped growth ("neck"), with the mouth opening at head end. The females fix immovably on the roots of infested plants, embedding their necks into root tissues, and the cysts are found in soil (Kiryanova, Kral, 1969).

Globoderas overwinter in soil as eggs and encysted larvae, well-protected from unfavorable environmental factors. The cyst is a protective shell made up from the female body in unfavorable conditions, with ten to hundreds of eggs and larvae that can survive for several years. The larvae emerge in spring, when the soil temperature reaches $8-10{ }^{\circ} \mathrm{C}$. The future females seek out the host plant roots, enter them and after two molts become adult females. Young females emerge from the roots but remain attached to them via necks. The female nematodes are initially white, but become golden while laying eggs, browning and darkening when they die and form cysts. The males mature in soil, seek out females and die after fertilization. At the optimal temperature $\left(18-20^{\circ} \mathrm{C}\right)$ the life cycle occurs in $38-48$ days, at lower temperature of $15-17^{\circ} \mathrm{C}$ it happens more slowly, in 65-80 days. The specialized parasite infects potatoes as the main host, and several other nightshades (tomatoes, peppers, eggplants, and weeds of this family) (Butorina et al., 2006).

The annual potato crop losses from globoderosis worldwide are estimated at $12.2 \%$ (Pylypenko, 2002). American scientists believe that the golden globodera has such a high pathogenicity and ability to survive and spread that, without proper control, it can cause complete (100\%) crop loss. Harmfulness of the potato nematode is manifested only at a certain level of infestation of soil. If that is less than 20 eggs per $100 \mathrm{~cm}^{3}$ of soil, the potato nematode is not harmful. Decrease in tuber yield begins at the level of infestation of 1-5 thousand of larvae $/ 100 \mathrm{~cm}^{3}$ of soil. That level may develop 5-6 years after single cysts enter the soil (Brodie, 1989). Every 20 eggs/g of soil causes a loss of $2 \mathrm{t} /$ ha of potatoes. If the amount is up to 10 eggs/ $\mathrm{g}$ of soil, the plants themselves can offset the negative impact, if it is 10 to 50 eggs/g, the yield will likely be reduced (Dekker, 1972). In the presence of 10000 larvae/100 $\mathrm{cm}^{3}$ of soil, $50 \%$ crop losses have been observed. When growing susceptible varieties of potatoes in monoculture, the pest population increases from year to year, and when the abundance of G. rostochiensis reaches 15-25 000 larvae/ $100 \mathrm{~cm}^{3}$ of soil, almost no tubers are obtained (Makovskaya, 1990; Nazarova, 2002).

The cyst nematode Globodera rostochiensis Woll. is one of the most widely distributed potato pathogens. According to the European Plant Protection Organization, it is found on all continents. In Europe, globodera harms potato plants in 33 countries. It is found in 13 countries in North, Central and South America, and in 7 African and 8 Australasian countries. The former republics of the U.S.S.R., where potato nematode outbreaks were recorded from 1948 to 1957 (Nikitin, 1972; Pylypenko, 2002; Sigareva et al., 1999), later became areas of widespread parasite infestation.

In Ukraine, the golden potato nematode was first observed in the early 1960s. According to the literature, this species was introduced in Ukraine from the Baltic countries with contaminated garden material. At the end of the twentieth century, total area of G. rostochiensis distribution in Ukraine was 5812.7 ha and covered the whole area favorable for potato production in the country (Pylypenko, 1998). Another species G. pallida was first recorded in Ukraine (Transcarpatia) in 2004 (Kochanova et al., 2004; Pylypenko et al., 2005).

\section{Material and methods}

We examined private farms in 5 districts of Chernihiv Region and 1 district of Kyiv Region during summer seasons of 2017-2018. The highest number of settlements was assessed in Koryukivsky (4) and Chernihivsky (3) Districts of Chernihiv Region, in other districts we chose single settlements (table 1). The survey in Koryukivsky District was conducted in Kholmy town (5 plots), Brech village (8 plots), Zhuklia village (6 plots) and Siadryne village (10 plots). In Chernihivsky District, 3 settlements were assessed: Ivanivka village (10 plots), Yahidne village (12 plots) and Kolychivka village (4 plots). In Horodniansky District, 10 plots were studied in Smychyn village, and in Novhorod-Siversky District, 10 plots were assessed in Novhorod-Siversky City. The farm plots were examined according to standard methods (Siddiqi, 1986; Kiryanova, Kral, 1969). Collected $500 \mathrm{~cm}^{3}$ volume samples of soil were taken manually from a depth of 15$20 \mathrm{~cm}$ in the amount of 5 pieces from a plot of 10 acres. Population density of golden cyst potato nematode in soil was calculated by the number of cysts and mean number of larvae and eggs in cysts in $100 \mathrm{~cm}^{3}$ of soil using the flotation-funnel technique (Sigareva, 1986). Soil samples were thoroughly mixed, sifted through a sieve with $2 \mathrm{~mm}$ diameter of hole and dried to air-dry state. Next, the soil sample with a volume of $100 \mathrm{~cm}^{3}$ was poured into a 11 beaker, adding water to $2 / 3-3 / 4$ of volume. The soil was stirred with a glass rod for 2- 
3 minutes, and the contents were allowed to settle for 5 minutes to the formation of precipitate. The upper layer of water with cysts and organic particles was poured on a sieve with $0.1-0.2 \mathrm{~mm}$ diameter of hole. This procedure was thrice repeated, adding water to the beaker. The precipitate was washed off using a rubber bulb into a funnel with a built-in filter. After straining, the filter was removed from the funnel and viewed under an MBS-9 microscope. The cysts found on the filter were counted and transferred to a drop of water on slide. 20 to 50 cysts were torn using a dissecting needle in order to count the mean number of eggs and larvae $(\mathrm{e}+\mathrm{l})$ per cyst and to evaluate their viability. The number of local populations of globoderas was evaluated according to: low abundance, less than $1000 \mathrm{e}+1 / 100 \mathrm{~cm}^{3}$; average abundance, $1000-5000 \mathrm{e}+1 / 100 \mathrm{~cm}^{3}$; and high abundance, more than $5000 \mathrm{e}+1 / 100 \mathrm{~cm}^{3}$.

Globodera species was identified by morphological features. The metric parameters of females (as cysts) are $0.38-1.07 \times 0.28-0.97 \mathrm{~mm}$. Young maturing females are initially white, turning in time to golden. The length of stylet is $22.9 \mathrm{mkm}$. Length of anal-vulval plate is $22.4 \mathrm{mkm}$, length of vulva slit is $9.7 \mathrm{mkm}$, distance from anus to plate is $60.0 \mathrm{mkm}$. The mature cysts are brown to dark brown. Young females have egg poaches without eggs, the cysts lack the egg poaches. Males are vermiform, $0.91-1.23 \mathrm{~mm}$ in length. Head is annular, number of rings ranges from 5-6 to 8-9, cephalic capsule is well-developed. Stylet is 27-28 mkm long with well-developed knob. Spicules are slightly curved, pointed, and 31-36 mkm long. Infectious second stage larvae are 270$320 \mathrm{mkm}$ long and 18-23 mkm wide. Hyaline tail end is as long as stylet (24-27 mkm) (Dekker, 1972; Kiryanova, Kral, 1969).

We have also used the reports of the State Service for food safety and consumer protection of Ukraine on the distribution of $G$. rostochiensis in Ukraine, particularly in Kyiv and Chernihiv Regions. The areas infested with globoderas are analyzed for each region. By this parameter, the regions are characterized into 6 categories. Category I is defined as less than 1 ha of globodera-infested area. Category II includes regions with 1 to 50 ha of globodera-infested soils. Category III includes regions with 50 to 100 ha of infested soils. Category IV is for regions with 100-500 ha of infested soils. If 500 to 1000 ha are infested, the region is classed in category V. The highest category, VI, is for regions with more than 1000 ha of globodera-infested soils.

\section{Results and discussion}

Of all the parasitic pests of potatoes, the golden potato cyst nematode is considered the most difficult to control. The best prevention measures so far include crop rotation and growing nematode-resistant varieties. The implementation of agricultural measures and choice of potato variety depend on the abundance rate of this nematode in soil. Hence, the integrated system of protective measures intended to "decontaminate" soils from potato nematodes must take into account the levels of G. rostochiensis infestation and the mapped zones of distribution of that pathogen.

\section{Distribution of Globodera rostochiensis in Chernihiv and Kyiv Regions}

We conducted monitoring surveys of Globodera rostochiensis (Ro-1) nematode infestation at the private farm plots in 5 districts of Chernihiv and 1 district of Kyiv Regions (fig. 1) in 2017-2018.

The chosen districts differed by the numbers of settlements and examined private farm plots. Total area of the studied farm plots in Koryukivsky District was 5.85 ha, G. rostochiensis (Ro-1) was found at $4.6 \mathrm{ha}(78.6 \%)$. The local mean abundance of nematodes was $1549(20-15757) \mathrm{e}+1 / 100 \mathrm{~cm}^{3}$, which is average soil infestation.

The highest number (12) of studied farm plots in Chernihivsky District, 3.9 ha in total, was located in Yahidne village. The golden nematode was found at 3.6 ha $(92.3 \%)$ with abundance rate of $1195(20-4465)$ e $+1 / 100 \mathrm{~cm}^{3}$. In other districts, single settlements were chosen for study. Thus, the nematode abundance was $4662(237-6572) \mathrm{e}+1 / 100 \mathrm{~cm}^{3}$ (average level of infestation) in Kyselivka village of Mensky District; in Smychyn village of Horodniansky District, it was low, $886(30-5510)$ e $+1 / 100 \mathrm{~cm}^{3}$; in Novhorod-Siversky City of Novhorod-Siversky District, it was average, $2966(15-23237)$ e $+1 / 100 \mathrm{~cm}^{3}$. The highest rate of infestation, $8730(91-21486)$ e $+1 / 100 \mathrm{~cm}^{3}$ was recorded in Kozyntsi village of Borodiansky District, Kyiv Region (fig. 1).

In all the collected samples only G. rostochiensis was found. Individuals corresponding to G. pallida in morphological and morphometric characteristics (Pylypenko, 2014) were not identified. 

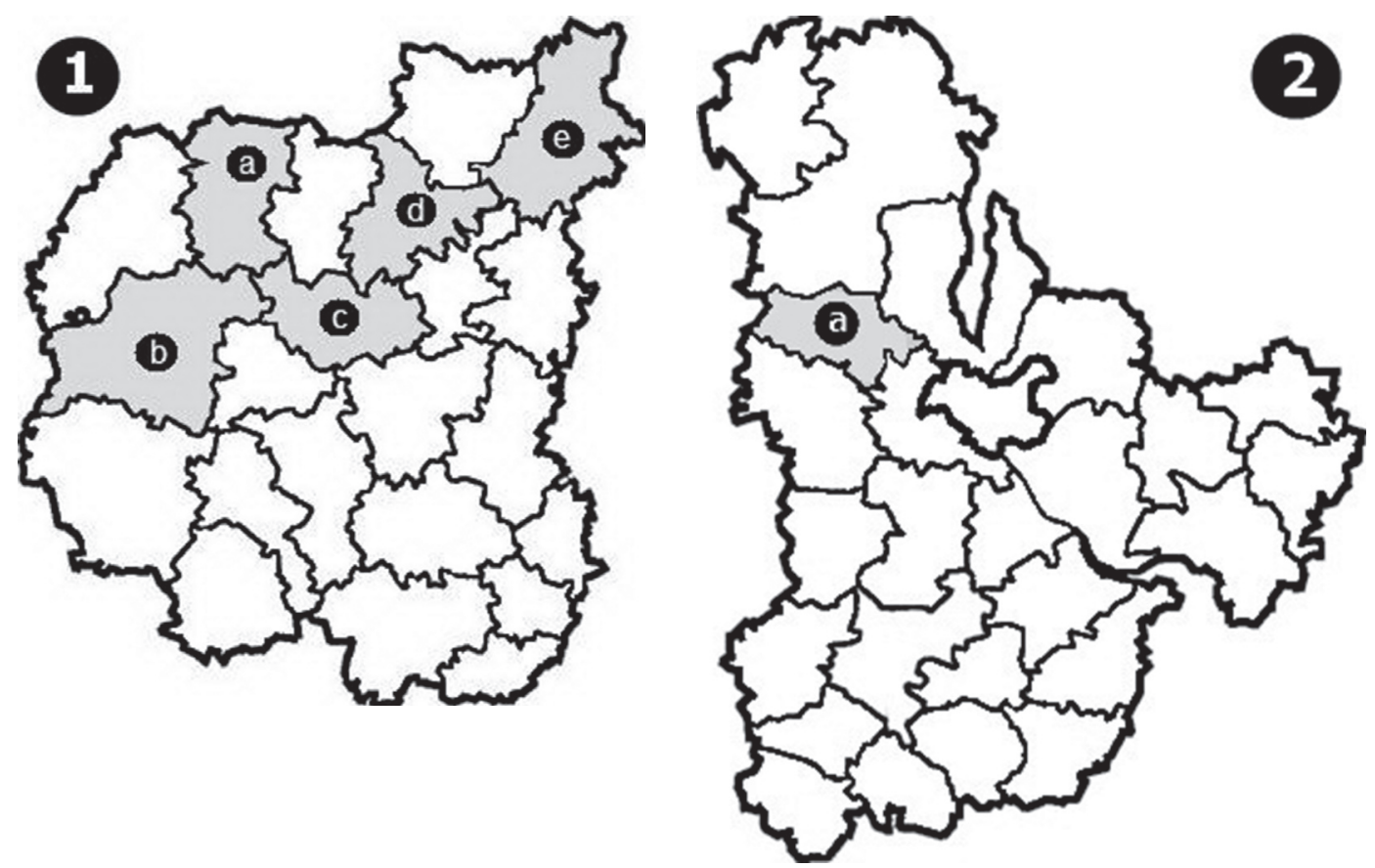

Fig. 1. Study area of monitoring survey of G. rostochiensisin soils of private farm plots (own data, 2017-2018) 1. Chernihiv Region: a - Horodniansky District; b - Chernihivsky District; c - Mensky District; d Koryukivsky District; e - Novhorod-Siversky District. 2. Kyiv Region: a - Borodiansky District.

Table 1. Results of monitoring of Globodera rostochiensis (Ro-1) infestation of private farm plots in Chernihiv and Kyiv Regions (2017-2018)

\begin{tabular}{|c|c|c|c|c|c|}
\hline $\mathrm{N}$ & District & Settlement & $\begin{array}{c}\text { Number of plots } \\
\text { (samples) })^{*}\end{array}$ & Study area, ha & $\begin{array}{c}* * \text { Abundance of } G l . \\
\text { rostochiensis }\end{array}$ \\
\hline \multicolumn{6}{|c|}{ Chernihiv Region } \\
\hline 1 & Chernihivsky & Ivanivka vil. & $10(78)$ & 1.55 & $867(20-3646)$ \\
\hline 2 & & Kolychivka vil. & $4(30)$ & 0.6 & $1840(675-3723)$ \\
\hline 3 & & Yahidne vil. & $12(88)$ & 1.75 & $878(20-4465)$ \\
\hline 4 & Mensky & Kyselivka vil. & $4(20)$ & 0.38 & $4662(2370-6572)$ \\
\hline 5 & Koryukivsky & Kholmb town & $5(70)$ & 1.35 & 457 (90-1069) \\
\hline 6 & & Brech vil. & $8(80)$ & 1.6 & $1483(98-4584)$ \\
\hline 7 & & Zhuklia vil. & $6(56)$ & 1.13 & $274(30-1280)$ \\
\hline 8 & & Siadryne vil. & $10(90)$ & 1.77 & $3983(20-15757)$ \\
\hline 9 & Horodniansky & Smychyn vil. & $10(155)$ & 3.1 & $886(30-5510)$ \\
\hline 10 & $\begin{array}{c}\text { Novhorod- } \\
\text { Siversky }\end{array}$ & $\begin{array}{l}\text { Novhorod- } \\
\text { Siversky city }\end{array}$ & $10(45)$ & 0.88 & $2966(15-23237)$ \\
\hline \multicolumn{6}{|c|}{ Kyiv Region } \\
\hline 1 & Borodiansky & Kozyntsi vil. & $9(45)$ & 0.91 & $8730(91-21486)$ \\
\hline In total & 6 & 11 & $88(757)$ & 15.02 & 3331 (15-23237) \\
\hline
\end{tabular}

Note. ${ }^{\star}$ The number of plots from surveyed district and the number of samples per area; ${ }^{* *}$ abundance of larvae and eggs of Globodera rostochiensis (Ro-1) in $100 \mathrm{~cm}^{3}$ of soil, average value (min-max). 
Recently, the area infested with golden nematodes reduces in Chernihiv Region (table 1). According to the reports of the State Service for food safety and consumer protection, in Chernihiv Region the infested area was 804.26 ha in 2016, 798.2 ha in 2017, and 608.2 ha in 2018. Today, areas with the highest infestation are in Chernihivsky (195.13 ha), Snovsky (130.95 ha) and Horodniansky (81.52 ha) Districts, the least infested area is in Kulykivsky District (2.37 ha).

The levels of G. rostochiensis (Ro-1) infestation in Kyiv Region are average. Total infested area is 68.39 ha, of which 41.24 ha in Borodiansky District, 13.2 ha in Vyshhorodsky District and 11.7 in Makarivsky District. Smaller areas (approx. 1 ha) are recorded in Ivankivsky and Kyivo-Sviatoshinsky Districts.

The distribution of golden nematode in the Northwestern Ukraine was assessed in the analysis of the Survey of distribution of quarantined organisms in Ukraine in 2018, conducted by the State Service of food safety and consumer protection of Ukraine based on the data of annual phyto-sanitary monitoring.

The problem of globoderosis is rather severe in Ukraine. At the beginning of 2018, 4474.07 ha of soils were infested with the potato cyst nematode in 18 regions of Ukraine.

Sumy Region is leading by the area of infested soils, 1015.29 ha. Other soils, significantly affected by the cyst nematode, are located in Volyn, Rivne and Chernihiv Regions (949.13, 672.52 and 608.2 ha, respectively). These are the major regions of potato production. The pest is found at smaller areas (181.5-375.02 ha) in Ternopil, Zhytomyr, Vinnytsa and Cherkasy Regions.

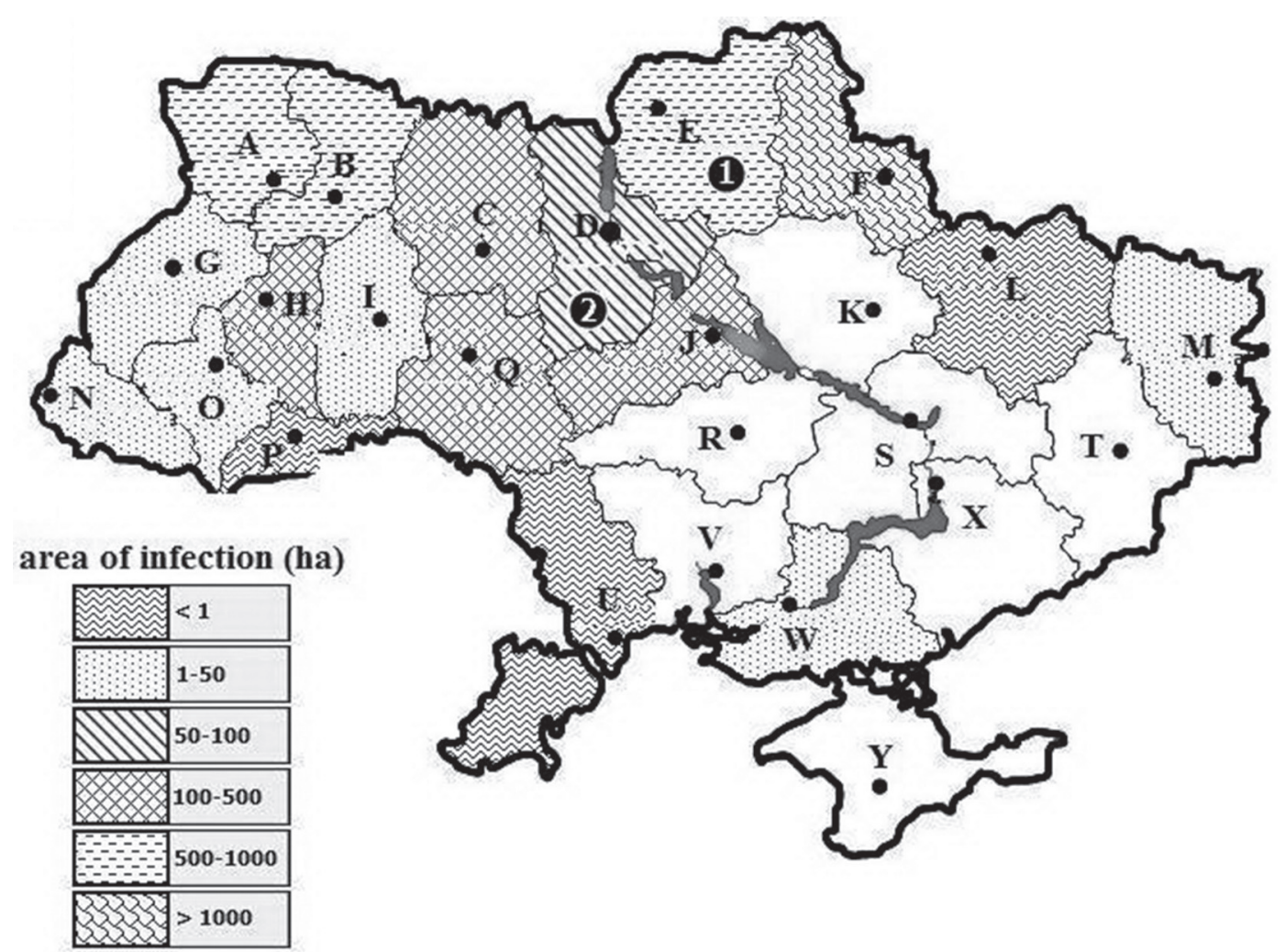

Fig. 2. Occurrence of Golden potato cyst nematode, Globodera rostochiensis, on the territory of Ukraine: A - Volynska; B - Rivnenska; C - Zhytomyrska; D - Kyivska; E - Chernihivska; F - Sumska; G Lvivska; H - Ternopilska; I — Khmelnytska; J - Cherkaska; K — Poltavska; L — Kharkivska; M — Luhanska; $\mathrm{N}$ - Zakarpatska; O - Ivano-Frankivska; P - Chernivetska; Q - Vinnytska; R - Kirovogradska; S Dnipropetrovska; T - Donetska; U — Odeska; V - Mylolaivska; W - Khersonska; X - Zaporizka; Y - AR Krym. 
The soils of Kyiv, Lviv, Khmelnytsky and Zakarpattia Regions are considerably less infested with G. rostochiensis. In Kherson, Ivano-Frankivsk and Luhansk Regions, the soil infestation is weak, found at 3.93-8.0 ha. Single foci of the golden nematode, less than 1 ha in area, are found in Chernivtsi, Odesa and Kharkiv Regions of Ukraine. There, the nematode has occurred in recent years, and has not yet spread far. In most of Central and Southern Ukraine (Poltava, Kirovohrad, Dnipropetrovsk, Mykolaiv, Zaporizhzhia, Donetsk Regions and AR Crimea) G. rostochiensis was not recorded (fig. 2).

Thus, G.rostochiensis (Ro-1) is currently found in 18 of 25 regions of Ukraine. The area of infested soils greatly varies in different regions, from less than 1 ha to more than 1000 ha.

\section{Conclusion}

According to our study, the private farms and backyards are important microhabitats for Globodera rostochiensis to spread and infest other farms, including industrial. This potato cyst nematode was found in all (11) studied settlements of Chernihiv and Kyiv Regions, where soil samples were collected in 2017-2018. It populated $75 \%$ of examined plots, 12.66 of 15.02 ha or $84.4 \%$ of study area. The abundance of eggs and larvae of globoderas corresponded to the average rate of infestation of soil. The golden nematode infestation of potato crops of private farm plots varied greatly. Frequently, the abundance of eggs and larvae of globoderas was low, 15-885 e +1/100 $\mathrm{cm}^{3}$ (less than $1000 \mathrm{e}+1 / 100$ $\mathrm{cm}^{3}$ of soil).

Mostly the pest abundance was in range of $1069-4584 \mathrm{e}+1 / 100 \mathrm{~cm}^{3}$ in the studied soil samples. High rate of globodera infestation was rarely observed in soil, with abundance of eggs and larvae at 5510-23237 e $+1 / 100 \mathrm{~cm}^{3}$ (more than $5000 \mathrm{e}+1 / 100$ $\mathrm{cm}^{3}$ ). The generalized abundance of golden globodera was $2252 \mathrm{e}+1 / 100 \mathrm{~cm}^{3}$ in the pooled soil samples of the private farm plots of Chernihiv Region, which points to the average rate of soil infestation. Mean pest abundance ranged from 887 to $4663 \mathrm{e}+1 / 100$ $\mathrm{cm}^{3}$ in different districts. In Kyiv Region, 9 study plots were examined in 1 district. High abundance of globodera $\left(8730 \mathrm{e}+1 / 100 \mathrm{~cm}^{3}\right)$ was found in $90 \%$ of the studied area $(0.82$ ha of $0.91 \mathrm{ha})$. Hence, the private farm plots of the studied settlements of that district are characterized by mostly average rate of golden nematode infestation and high percentage of infested area. At the same time, home-grown potatoes provide the vegetable market with a significant harvest of tubers of this traditionally important for Ukraine crop.

We also analyzed the reports of the State Service of food safety and consumer protection of Ukraine on the distribution of golden globodera according to data on phyto-sanitary monitoring conducted in 2018. At that point, Globodera rostochiensis was recorded in 18 of 25 regions of Ukraine. The areas infested by that rather harmful for potatoes pest differ significantly in various regions.

The regional distribution of golden nematode is usually categorized depending on the area infested by this soil nematode, into 1 of 6 possible categories. Three regions in Ukraine belong to category I. Six other regions of Ukraine are classified as category II. In 1 region, the relevant indices correspond to category III. Category IV includes four regions, category $\mathrm{V}$ three regions. The last one, category VI, is represented only by 1 region. Overall, the infested areas are rather small, less than 500 ha, in most of the regions (14 of 18). The golden nematode is not recorded in 7 regions of Ukraine and AR Crimea by now.

We made a more detailed analysis of the monitoring reports of the spread of golden potato nematode in Chernihiv and Kyiv Regions by the State Service of food safety and consumer protection of Ukraine, where our research was conducted, and 
revealed certain regional features. In Chernihiv Region, the golden globedera is more widespread and recorded in half of the districts of this region. At the same time, in Kyiv Region, the golden globodera was found only in $20 \%$ of districts, the area of infested soils was much smaller than 0.95-41.24 ha. According to the State Service of food safety and consumer protection of Ukraine, in recent years the area of soil infested with globodera tended to decline. The persistence of this trend needs to be confirmed by monitoring the spread of this quarantine pathogen of potato over the next few years.

It is symptomatic that we found the golden nematode in all settlements of Chernihiv and Kyiv Regions, where the soils of $75 \%$ of surveyed plots were infested, which is $84.4 \%$ of their total area, and the generalized numbers of eggs and larvae of globodera are at average levels. Thus, monitoring this harmful pest in a particular region using the method of detecting globodera cysts in the agricultural soils and taking into account their area, is an important first step in controlling the spread of this quarantine nematode in Ukraine. At present, it must be supplemented by a quantitative method of counting cysts, live larvae and globodera eggs in $100 \mathrm{~cm}^{3}$ of soil in farms of various types growing marketable potatoes and in home gardens. This will allow controlling the spread of this quarantine species in Ukraine more effectively.

\section{References}

Brodie, B. B., Mai, W. F. 1989. Control of the golden nematode in the United States. Annu. E. Rev. Phytopathol., Palo Alto (Calif.), 27, 443-461.

Butorina, N. N., Zinovieva S. V., Kulinich, O. A. etc. 2006. Applied Nematology. Nauka, Moscow, 1-350 [In Russian].

Dekker, H. 1972. Nematodes of plants and the fight against them. Kolos, Moscow, 180-192 [In Russian].

Kiryanova, E. S., Kral, E. L. 1969. Parasitic nematodes of plants and measures to combat them. Nauka, Leningrad, Vol. 1, 1-447 [In Russian].

Kochanova, M., Marek, M., Zouhar, M., Pylypenko, L., Rysanek, P. 2004. Report first of Globodera pallida occurrence on the area of Ukraine. Acta fytotechnica et zotechnica. Special Number: Proceedings of the XVI Slovak and Czech Plant Protection Conference, Vol. 7, $136-137$.

Makovskaya, S. A. 1990. On the prognosis of harmfulness of golden potato cyst nematode. Proceedings of All-Union Congress (Novosibirsk, March 20-23, 1990) Ekol. (epifitotiol.) osnovy zaschity rasteniy ot bolezney. Novosibirsk, 27-28 [In Russian].

Nazarova, N. V. 2002. Effect of resistant and susceptible potato varieties on population density of golden potato nematode in North-Western region. Materials of 1 st Vseros. Conf. po immunitetu rasteniy $k$ bolezniam $i$ vrediteliam, posv. 300-letiyu Sankt-Peterburga. SPb., 40-41 [In Russian].

Nikitin, V. S. 1972. Findings of potato nematode in Ukraine. Nematodnyye bolezni s.-kh. kultur i mery bor'by s nimi. Moscow, $95-96$ [In Russian].

Pylypenko, L. A. 1998. Distribution of Globodera rostochiensis Wollenweber, 1923 (Tylenchida, Heteroderidae) in Ukraine. Vestnik Zoologii, 32 (5-6), 139-142 [In Ukrainian].

Pylypenko, L. A. 2002. Nematode-resistant potato varieties in the system of anti-nematode measures: problems and perspectives. Zakhyst $i$ karantyn roslyn, 48, 104-113 [In Ukrainian].

Pylypenko, L. A., Uehara, T., Phillips, M. S., Sigareva, D. D., Blok, V. C. 2005. Identification of Globodera rostochiensis and G. pallida in the Ukraine by PCR. European Journal of Plant Pathology, 111, 39-46.

Pylypenko, L. A. 2014 Phytosanitary control of quarantine and potentially dangerous nematode species in Ukraine: a conceptual framework. Manuscript. Thesis for the scientific degree of Doctor of science in biology. The speciality 06.01.11-phytopathology. Kyiv, 2014.

Siddiqi, M. R. 1986. Tylenchida parasites of plants and insects. CAB International, Wallingford, UK, $1-645$.

Sigareva, D. D. 1986. Methodical studies on the identification and recording of parasitic nematodes in field crops. Urozhay, Kiev, 1-41 [In Russian]. 
Sigareva, D. D., Pylypenko, L. A., Osypchuk, A. A., Taktayev, B. A. 1999. Assessment of selection material's tolerance to potato nematode (Globodera rostochiensis Woll.). Agrar. visn. Prychornomor.: zb. nauk. pr. Biologichni $i$ c.-g. nauky, 3 (6). Part II: Agronomy. 236-238 [In Ukrainian].

Received 1 September 2020

Accepted 3 March 2021 